cemoti $\begin{aligned} & \text { Cahiers d'études sur la Méditerranée } \\ & \text { orientale et le monde turco-iranien }\end{aligned}$

13 | 1992

L'immigration turque en France et en Allemagne

\title{
La population de la Turquie en 1990
}

\section{Marcel BAZIN}

\section{OpenEdition}

\section{Journals}

Édition électronique

URL : http://journals.openedition.org/cemoti/360

DOI : $10.4000 /$ cemoti.360

ISSN : $1777-5396$

Éditeur

AFEMOTI

Édition imprimée

Date de publication : 1 janvier 1992

Pagination :

121-134

ISSN : 0764-9878

Référence électronique

Marcel BAZIN, «La population de la Turquie en 1990 », Cahiers d'études sur la Méditerranée orientale et le monde turco-iranien [En ligne], 13 | 1992, mis en ligne le, consulté le 08 septembre 2020. URL : http:// journals.openedition.org/cemoti/360 ; DOI : https://doi.org/10.4000/cemoti.360

Ce document a été généré automatiquement le 8 septembre 2020

Tous droits réservés 


\title{
La population de la Turquie en 1990
}

\author{
Marcel BAZIN
}

\section{RÉSUMÉS}

Cet article commente les premiers résultats, quantitatifs, du recensement du 21 octobre 1990. La Turquie comptait alors 56473035 habitants contre 50664458 habitants le 20 octobre 1985. La croissance démographique s'est légèrement ralentie, avec un taux d'accroissement annuel moyen de $2,17 \%$ contre $2,48 \%$ pendant la période intercensitaire $1980-85$. Cette croissance globale est la moyenne de taux d'accroissement départementaux très contrastés. Trois pôles de croissance démographique forte, la Marmara orientale incluant le Grand Istanbul et Bursa, la côte méridionale d'Izmir au golfe d'Iskenderun, et le Sud-Est kurde, s'opposent ainsi au Nord-Est intérieur et littoral où 15 départements ont perdu des habitants entre 1985 et 1990. Par ailleurs, la population urbaine a renforcé sa prédominance, comptant désormais $59 \%$ de la population totale. Les villes les plus dynamiques appartiennent à toutes les tranches dimensionnelles, de la métropole stambouliote qui a accentué son avance sur la capitale politique Ankara aux nombreuses bourgades nouvellement promues au rang de sous-préfecture. 